\title{
Interviewing The Client
}

Michael D. Akers, (Email: michael.akers@ marquette.edu), Marquette University

Robert Yahr, (Email: grate4wisc@aol.com), Marquette University

\begin{abstract}
This paper examines an assignment where students taking either an introductory auditing students or an accounting communications course interview a client to gain an understanding of internal control and the interview process. Students document the results of the interview in a memorandum. The paper provides detailed information regarding the design and implementation of a portion of the internal control system. The three main objectives of the assignment are 1) to provide students with the opportunity to demonstrate, develop, and enhance their communication skills; 2) to convey a realistic picture of the accounting environment; and 3) to familiarize students with a typical responsibility of entry-level accountants.
\end{abstract}

\section{INTRODUCTION}

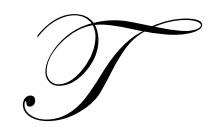

he purpose of this paper is to present an assignment where introductory auditing students or students in an accounting communications course interview a client to gain an understanding of internal control. The results of the interview are then documented in a memo. This project gives the students a "real world" experience and enhances their communication skills. The first section of the paper examines the interviewing skills that are necessary for entry-level accountants. The objectives, design and implementation of the assignment are discussed in the second section. Concluding comments are presented in the final section.

\section{INTERVIEWING SKILLS}

Communication and interviewing skills are important for entry-level accountants. Accountants must gather data, interview employees of the client's organization, and interact with other members of the audit team. Mastering effective communication skills maximizes results in an auditing environment. If students learn communication skills in the academic world, they will enter the professional world better equipped to effectively question clients to solicit needed responses.

The Institute of Internal Auditors (IIA) defines interviewing as "a specialized form of communication used to gain information and assist in evaluation (Harmeyer 1)." In 1984 the IIA published a book entitled Conducting Internal Audit Interviews, which is useful in preparing auditors for their first client interview. It notes, "The difference between successful audits and ineffective audits often depends on the skills of internal auditors in conducting interviews. They can improve their interviewing skills by evaluating their present techniques and identifying those that need to be eliminated and/or sharpened (Harmeyer 2)." A six step process is outlined: 1) preparing, 2) scheduling, 3) opening, 4) conducting, 5) closing, and 6) recording.

The first two steps precede the actual interview. Preparation is the first and most important step in the process. The number one rule is never go into the interview cold. The interviewer should consider several factors, such as 1) the interview environment, 2) the interviewee's sensitivity to the interview process, 3) human behavior implications, and 4) the interviewer's abilities to conduct interviews prior to conducting the interview. A person can never be too prepared. The second step is scheduling the interview. The primary issues are to be flexible and accommodating to the interviewee.

The third step in the process is the interview itself. An interviewer should initiate the conversation with some type of ice breaker, followed by an explanation of the interview's purpose and how the results will be used. At this point, there should then be a clear transition to the next step in the process, which is the heart of the interview, asking 
the questions. There are various types of questions that can be used in the interview, such as factual, explanatory, justifying, leading, hypothetical, alternative, and coordinating questions. Regardless which kind of questions are asked, the interviewer must be well prepared with as much background information on the interviewee and his/her company as possible. Furthermore, the interviewer must have good listening skills. Communication is not a one-way street. It takes both speaking and listening to maintain effective communication and to assess where follow-up questions would be beneficial.

The closing of the interview is also very important. The interviewer needs to know when to stop asking questions, which usually comes at the end of the allotted time or after all prepared questions have been asked. Unfortunately, these two events usually do not occur simultaneously. Regardless when the interview ends, interviews should always end on a positive note.

Finally, the last step of the process is to record the interview, which should be done promptly after the interview is completed. Notes taken during the interview should be reviewed, organized, and rewritten, if necessary. This process should be done when the interview is still fresh in the interviewer's mind (Harmeyer, pp. 3-25). For example, the interviewer might type out answers to those questions asked during interview immediately afterwards and then write the actual interview memo later.

The above process is merely an overview of the skills necessary to conduct an interview. Students should be taught the necessary communication skills before the assignment discussed in this paper, either in a separate communications class or early in the introductory auditing class. For example, Marquette University offers a new communications course entitled "Professional Communications for Accountants." The course provides a comprehensive examination of the major forms of communication used in the accounting profession, as well as instruction in business writing and speaking. Currently, this course is taken as a prerequisite to the introductory auditing course. Thus, students can be taught the proper communication and interviewing skills before this assignment, whether it is used in the auditing or communications classes.

\section{ASSIGNMENT}

\section{Objectives}

Students must learn the proper skills and techniques for communication in a business environment and put those learned skills into practice. Regardless whether the class is auditing or communications, three main purposes exist for having students interview the client and document the results in a memorandum:

1. The assignment provides students with the opportunity to demonstrate, develop and enhance their communication skills (speaking, listening, understanding and documenting their interview in a written memorandum).

2. The assignment conveys a realistic picture of the accounting environment.

3. The assignment allows students to become familiar with a typical responsibility of an entry-level accountant.

\section{Design and Implementation}

Originally this assignment was used in the auditing course for two semesters. The assignment is now used in our accounting communications course, which is a required course for the undergraduate accounting majors. The instructions and information provided to the auditing students and the client for the first semester, as well as a description of the execution and evaluation of the interview, is first discussed. Modifications made to the assignment for the second semester are examined next, followed by a discussion of further modifications to the assignment that have been made for the accounting communications course.

\section{Instructions and Information for Students-Syllabus}

On the first day of class, students enrolled in the auditing course were informed, during the presentation of the syllabus, that the course requirements included an interview of an employee of a fictitious client. The purpose, 
scheduling, timing, and evaluation of the interview, as well as the location of the client, were explained to the students. Appendix A presents the detailed information contained in the syllabus.

\section{Internal Control Information}

Once the chapter pertaining to control risk assessment is completed, the students were given a document (see Appendix B) that provided background information about a new client of the firm with whom they had recently begun employment. The document also explained to the students that their audit assignment was to interview a graduate student (a CPA who had returned to school to complete an MBA), owner of Moovy Theater, to obtain and document evidence regarding control procedures related to the sale of tickets and the collection and deposit of cash. Cash receipts from concession sales were specifically ignored.

The assignment focused on control procedures related to the cash of a movie theater for four specific reasons:

1. With rare exception, all students are familiar with the basic operations of movie theaters.

2. Control procedures related to the collection and deposits of box office cash at movie theaters are not overly complex or sophisticated.

3. Only basic control procedures had been covered in class.

4. Time constraints precluded using a detailed and difficult situation examining the entire control environment.

\section{The Interview}

Each student was allowed twenty minutes to conduct his/her interview. If the interview was not completed in twenty minutes, the owner informed the student that he had another appointment. To effectively use the time allotted, students were instructed to develop a list of questions before conducting the interview. The questions were to be developed using information from the text, class discussions, and the internal control situation (Appendix B). Although the interviews consisted primarily of students questioning the client, the graduate student also asked some questions of his own.

To reduce the likelihood of collaboration, three different internal control situations (see Appendices C, D, and E) were developed: poor, moderate, and strong internal controls. The students were not told that there were three different situations. They were told that the memo should be based solely on the interview and that the findings for each student could differ based on the questions asked during the interview.

The instructor informed the graduate student (owner) of the internal control situation that was to be used for each student. The assignment of the internal control situation was not done in an entirely random manner. Instead, the instructor purposely assigned different situations to students who were friends. The number of students assigned to each internal control situation was approximately the same (i.e., $33 \%$ for each group).

\section{Evaluation}

After the interview, the graduate student evaluated each student based on his perception on how well the interview was conducted. While this was a subjective evaluation, each student was assigned a score from 1 (not satisfactory) to 5 (very satisfactory). The general criteria used by the graduate student to differentiate students' level of performance are as follows:

1. Unprofessional demeanor; unprepared to adequately question the client;

2. Relatively unprofessional demeanor; some questions prepared, but a general lack of depth of understanding;

3. Relatively professional demeanor; questions relatively well prepared to demonstrate an understanding of basic, text book internal controls;

4. Professional demeanor; questions well prepared to demonstrate an understanding of basic internal controls as well as how those controls should be applied to the specifics of this case;

5. Professional demeanor; questions well prepared in relation to Moovy Theater and demonstrated ability to "think on their feet" and modify interview style (questions based upon client discussion). 
Two primary reasons exist for using a simplistic, subjective evaluation by the client. First, clients do evaluate, although informally, the performances of staff people. Second, clients often share their perceptions and evaluations with seniors, managers and partners, which can affect the evaluation of the staff accountants. Results of the evaluations are found in Exhibit 2.

\section{The Memorandum}

Based on their interviews, the students were then required to prepare a typed memorandum. The memoranda were subjectively graded by the instructor, independent of the graduate student's evaluation. While writing ability (grammar, punctuation, etc.) was considered, content had a greater impact in determining the grade.

The instructor knew the information that should be in each memorandum since he had assigned the internal control situations (poor, moderate, and good). Each memorandum was read at least twice by the instructor to ensure consistency in grading. The instructor then documented detailed comments, similar to review points by a senior, manager or partner, in the memorandum.

\section{Student Comments}

The students were also asked to evaluate the assignment qualitatively. During the last class meeting of the semester, the students were asked to document, anonymously, their likes and dislikes or any other thoughts regarding the assignment. Exhibit 1 presents a summary of the student comments.

Exhibit 1

Qualitative Evaluation

\begin{tabular}{|l|l|}
\hline \multicolumn{1}{|c|}{ Likes } & \multicolumn{1}{c|}{ Dislikes } \\
\hline$\bullet$ Real-world learning experience & $\bullet$ Purpose of self-evaluation was questioned \\
\hline$\bullet$ Reinforced the importance of the interview process & $\begin{array}{l}\bullet \text { Detailed comments regarding the client's evaluation were not } \\
\text { provided }\end{array}$ \\
\hline$\bullet$ Questions by the client forced students to think on their feet & $\begin{array}{l}\bullet \text { Limited guidance was provided by the instructor in the } \\
\text { development of the questions and the drafting of the } \\
\text { memorandum }\end{array}$ \\
\hline$\bullet$ Development of questions required students to think & $\bullet$ Time delay in receiving the graded memorandums \\
\hline$\bullet$ Reinforced the importance of the interview process & $\bullet$ Client asked questions \\
\hline & $\bullet$ Client was obnoxious/intimidating \\
\hline
\end{tabular}

A review of the students' comments shows that most of the students considered the assignment to be a worthwhile learning experience that should be continued. The "real-world" experience was particularly appealing to them. According to the graduate student, the vast majority of students seemed receptive to the assignment, demonstrating their commitment by appearing at the interview prepared with their questions, and, in some cases, even professionally dressed. Several students requested follow-up interviews, though they had to be refused in order to ensure fairness. This must be recognized as an inherent weakness of the assignment because practice often requires follow-up interviews.

Although the positive comments far outweighed the negative comments, the students identified some areas of concern. Most of their frustrations focused on three areas: 1) limited guidance provided by the instructor concerning the development of the questions and the drafting of the memorandum 2) behavior of the client and 3) evaluations.

The students' comments indicated that some of them would have preferred help in developing questions for the interview and they would have preferred more details about the format of the interview. The instructor purposely did not help the students develop their questions and provided limited guidance concerning the format of the memorandum. He wanted the students to think and apply the technical material discussed in class. He also wanted to 
see if the students could document their findings in a concise and organized manner; however, the students did have a valid point in that they should have received more guidance regarding the assignment.

Another area of concern was the client's behavior. Some of the students were surprised that the client was rude or intimidating. They expected the client to be friendly and courteous, and readily volunteer information regarding the internal control weaknesses of his own establishment. Some of the students were also surprised that the client asked them questions. The reason for the client's behavior was to create an experience for the students similar to what often happens in practice.

The third area of concern pertained to the evaluation process. The students identified three specific items. First, it took the instructor almost a month to return the graded memorandums because of the large number (79) involved and the time required to read each memorandum at least twice. Some of the students wanted feedback on a timelier basis. Second, detailed observations used by the graduate student to determine the points (1 to 5) awarded were not provided to the students. Some of the students wanted to know the reasons for the client's evaluation. This is a valid criticism and represents a limitation of the assignment. Third, the students did not understand the purpose of the self-evaluation, which was not explained to them until after they had completed their qualitative review. The purpose was to see if their assessment was consistent with the client's (graduate student) evaluation. The comparison of the client evaluation with the student self-evaluation is presented in Exhibit 2.

Exhibit 2

Client Evaluation vs. Student Self-Evaluation

\begin{tabular}{|c|c|c|c|c|c|c|c|c|c|}
\hline Scores & $\begin{array}{l}\text { Self } \\
1.0 \\
\end{array}$ & 2.5 & 3.0 & 3.5 & 4.0 & 4.5 & 4.6 & 5.0 & Total \\
\hline $\begin{array}{c}\text { Client } \\
1\end{array}$ & & & 1 & & & & & & $\begin{array}{c}1 \\
1.3 \%\end{array}$ \\
\hline 2 & & & 1 & & 1 & & & & $\begin{array}{c}2 \\
2.5 \% \\
\end{array}$ \\
\hline 3 & 1 & & 4 & 1 & 22 & 2 & 1 & 1 & $\begin{array}{c}32 \\
40.5 \%\end{array}$ \\
\hline 4 & & 1 & 12 & 1 & 13 & 2 & & 3 & $\begin{array}{c}32 \\
40.5 \% \\
\end{array}$ \\
\hline 5 & & & 3 & 1 & 5 & 2 & & 1 & $\begin{array}{c}12 \\
5.2 \%\end{array}$ \\
\hline Total & $\begin{array}{c}1 \\
1.3 \%\end{array}$ & $\begin{array}{c}1 \\
1.3 \%\end{array}$ & $\begin{array}{c}21 \\
26.6 \%\end{array}$ & $\begin{array}{c}3 \\
3.8 \%\end{array}$ & $\begin{array}{c}41 \\
51.9 \%\end{array}$ & $\begin{array}{c}6 \\
7.6 \%\end{array}$ & $\begin{array}{c}1 \\
1.3 \%\end{array}$ & $\begin{array}{c}5 \\
6.3 \%\end{array}$ & $\begin{array}{c}79 \\
100 \%\end{array}$ \\
\hline
\end{tabular}

An examination of Exhibit 2 shows that the same score was awarded by the client and the student in 18 of the 79 cases $(22.8 \%)$. It is interesting to note that, with one exception, all of the students who received a perfect score from the client awarded themselves a lower score. The results of the comparison shows the following: 1) the students had a difficult time evaluating their performance, 2) the students receiving lower scores considered their performance to be better than did the client, and 3) the students receiving higher scores were more critical of their performance than was the client.

\section{Second Semester}

The second time this assignment was used, the objectives remained the same, but the format was modified. Instead of using a graduate student as the client, two professionals from two of the then Big-Five public accounting firms represented the client. Students had to call the firm for an appointment and then provide their own transportation downtown, approximately 5 blocks from campus. Part of the student fee at our institution is used to provide each student with a bus pass; thus, this assignment did not create an additional cost for the students. The second semester results were very similar to the first semester. The use of practitioners provides an additional option for programs that want to integrate practice with academia or that have limited graduate assistants available. 


\section{Implementation}

Whichever option is chosen, it is important to remember two things when implementing this exercise. First, the proper communication and interview skills should be taught to the students beforehand. A major limitation of the assignment, as originally used in the auditing course, is that students were not given specific guidance on conducting interviews beforehand. Second, criteria used by the "client" to evaluate the level of performance of each student should be communicated up front. When students have learned the proper skills and know what is expected of them, the exercise achieves the objective of preparing the students for real-world accounting experiences.

\section{Accounting Communications Course}

The assignment is now used each semester in our accounting communications course. Students taking this course include primarily undergraduate students, with some having taken only Intermediate Accounting I and others being in their final undergraduate semester. Accordingly, some students have already taken or are currently taking the auditing course, while others have not. We discuss how we address this challenge and the relatively few changes to the assignment, all of which have been made to mitigate the limitations discussed above.

The students that have taken the auditing course have studied both the internal controls related to cash and the internal control elements. There are two ways that all students are provided with some basic knowledge of cash internal control procedures and the internal control elements. First, the instructor of the course provides the students with information from an auditing textbook related to cash controls. Second, the auditing instructor spends one class period discussing the internal control elements to the students in the communications class. While this session is a review for the students that have taken the auditing course, it has been our experience that internal controls are a challenging area for students and, accordingly, repetition is useful.

Prior to the interview, the communications students have been exposed to at least three topics not covered in the auditing course: suggestions for effective writing, memo writing, and interviewing. Thus, the students were held to a higher level of writing ability than were those in the auditing course. Textbooks used in the communications course include The Accountants Guide to Professional Communication by McKay and Rosa, published by Dryden (2000), and Writing That Works by Roman and Raphaelson, published by HarperResource (2000).

The instructions provided to the communications - but not auditing - students included these differences:

1. The graduate student provides times over a three to four day interval that he/she would be available. Once these hours have been determined, sign up times for the interview are documented on the instructor's door; in contrast, students had to personally schedule the interview with graduate student in the auditing course.

2. Students are told to wear professional attire (coats and ties for gentleman, comparable attire for women) for the interview, this was not a requirement stipulated in the auditing syllabus and accordingly some students dressed professionally while others did not.

3. Students must submit one copy of their prepared questions to the client (graduate student) at the start of the interview. The interviewee may make notes on these questions during the course of the interview if desired. However, these questions are eventually given to the instructor for grading. The auditing instructor did not collect and grade such questions.

4. The grade is based on three items:

$\begin{array}{lll}\text { a. } & \text { Prepared questions } & 15 \\ \text { b. } & \text { Interview evaluation by graduate student } & 20 \\ \text { c. } & \text { Memo on internal controls } & 40 \\ & \text { Total points available } & 75\end{array}$

5. Students receive a condensed copy of the graduate student's evaluation once grading of the memo is completed. Such evaluations were not provided to the auditing students. 
The background information for the assignment is essentially the same, with one exception. Students are instructed to ignore the cash/revenue stream generated by concession sales. Specific criteria, along with point allocations, have been developed and are used by the graduate student that does the interviews for the accounting communications course. The evaluation by the graduate student and practitioners for the audit students was subjective in nature. Exhibit 3 shows the most recent list of criteria, along with point allocations, used by the graduate student representing the client. As see from Exhibit $\mathrm{D}$, a total of 83 points are available for the entire assignment. Both the graduate assistant and accounting professor grade the assignment rigorously, so the additional eight points act as a buffer. To date the highest score has been 74 .

Exhibit 3

Criteria and Point Allocation used by the Graduate Student in Evaluating Interviews in the Accounting Communications Course

Student:

Prior (Concurrent) Auditing Course?:

\begin{tabular}{|c|c|c|}
\hline & Available & Student Score \\
\hline \multicolumn{3}{|c|}{ Overall Interview: } \\
\hline Clear and Concise Questions & 1.0 & \\
\hline Use of Open Ended Questions & 1.0 & \\
\hline Questions Flow and Follow-Up & 1.0 & \\
\hline Attentive to Answers & 1.0 & \\
\hline Eye contact/posture/confidence & 1.0 & \\
\hline Professional Attire & 1.0 & \\
\hline On Time & 1.0 & \\
\hline Interview Total & 7.0 & \\
\hline \multicolumn{3}{|c|}{ Internal Controls: } \\
\hline Ticket sales and cash collections & 2.0 & \\
\hline Reconciliation of tickets sold & 1.0 & \\
\hline Inquire about Cash Register (and follow-up) & 1.0 & \\
\hline Employee Background Check/Bonded & 2.0 & \\
\hline Cash Storage (from register to office) & 2.0 & \\
\hline Cash Receipts Journal & 1.0 & \\
\hline Cash Deposit Process (Office to bank) & 2.0 & \\
\hline Bank Reconciliation & 2.0 & \\
\hline Internal Control Total & 13.0 & \\
\hline \multicolumn{3}{|l|}{ Bonus Points } \\
\hline Additional Meaningful Questions/Suggestions & 2.0 & \\
\hline Both Employee Questions & 1.0 & \\
\hline Total Bonus Points & 3.0 & \\
\hline \begin{tabular}{|r|} 
Overall Total \\
\end{tabular} & 23.0 & \\
\hline \multicolumn{3}{|l|}{ Ungraded } \\
\hline Overall Internal Control Evaluation & 5.0 & \\
\hline
\end{tabular}

Once the memo has been completed, it is first given to the graduate student to read. If the memo contains items that were not discussed or otherwise contradicts the discussion during the interview, this is indicated on the memo when it is returned to the instructor. The instructor then grades the prepared questions (typically one point per control area mentioned plus two points if questions are both closed and open-ended) and the paper (Exhibit 4). Grading the description of the controls found requires care. The instructor's first grading basis for the memo focused on all control areas. However, it was quickly recognized that a student omitting an area (such as bank reconciliations) on both the prepared questions and the interview would not have that control discussed in the final memo. Consequently, grading the memo became slightly more subjective, as it must focus upon the areas that arose during the interview. This system might favor the student who did not uncover as much information at the interview as another student, but the instructor concluded that losing points for bank reconciliations in both the questions and interview was enough of a penalty, whereas the student including the bank reconciliation could conceivably receive full credit on all three items. Thus, a variable allocation of points for the controls discussion and suggestions for 
improvements was deemed to be the most appropriate approach for grading the memo. Examples of one student's prepared questions and subsequent memo are shown in Exhibits 5 and 6, as well as the overall grading on that assignment.

Exhibit 4

Grading Summary Given to Students, along with graded Memo and Interview Questions

Student:

Points Available

Student Score

Prepared Questions:

Areas:

Ticket Sales

Employees

Cash Removal and Storage

Cash Deposits

Recording and bank Reconciliation

Types:

One Open Question

Additional Open Questions (s)

Follow-Up Questions Included

Only Relevant Questions

verall Interview:

Prepared Questions Total

\begin{tabular}{|l|l|}
\hline 4.0 & \\
\hline 2.0 & \\
\hline 2.0 & \\
\hline 2.0 & \\
\hline 2.0 & \\
\hline
\end{tabular}

\begin{tabular}{|l|c|c|}
\hline Clear and Concise Questions & 1.0 & 1.0 \\
\hline Use of Open Ended Questions & 1.0 & \\
\hline Questions Flow and Follow-Up & 1.0 & \\
\hline Attentive to Answers & 1.0 & \\
\hline Eye contact/posture/confidence & 1.0 & \\
\hline Professional Attire & 1.0 & \\
\hline On Time & $\mathbf{7 . 0}$ & \\
\hline Interview Total & & \\
\hline
\end{tabular}

Internal Controls:

\begin{tabular}{|c|l|}
\hline 2.0 & \\
\hline 1.0 & \\
\hline 1.0 & \\
\hline 1.0 & \\
\hline
\end{tabular}

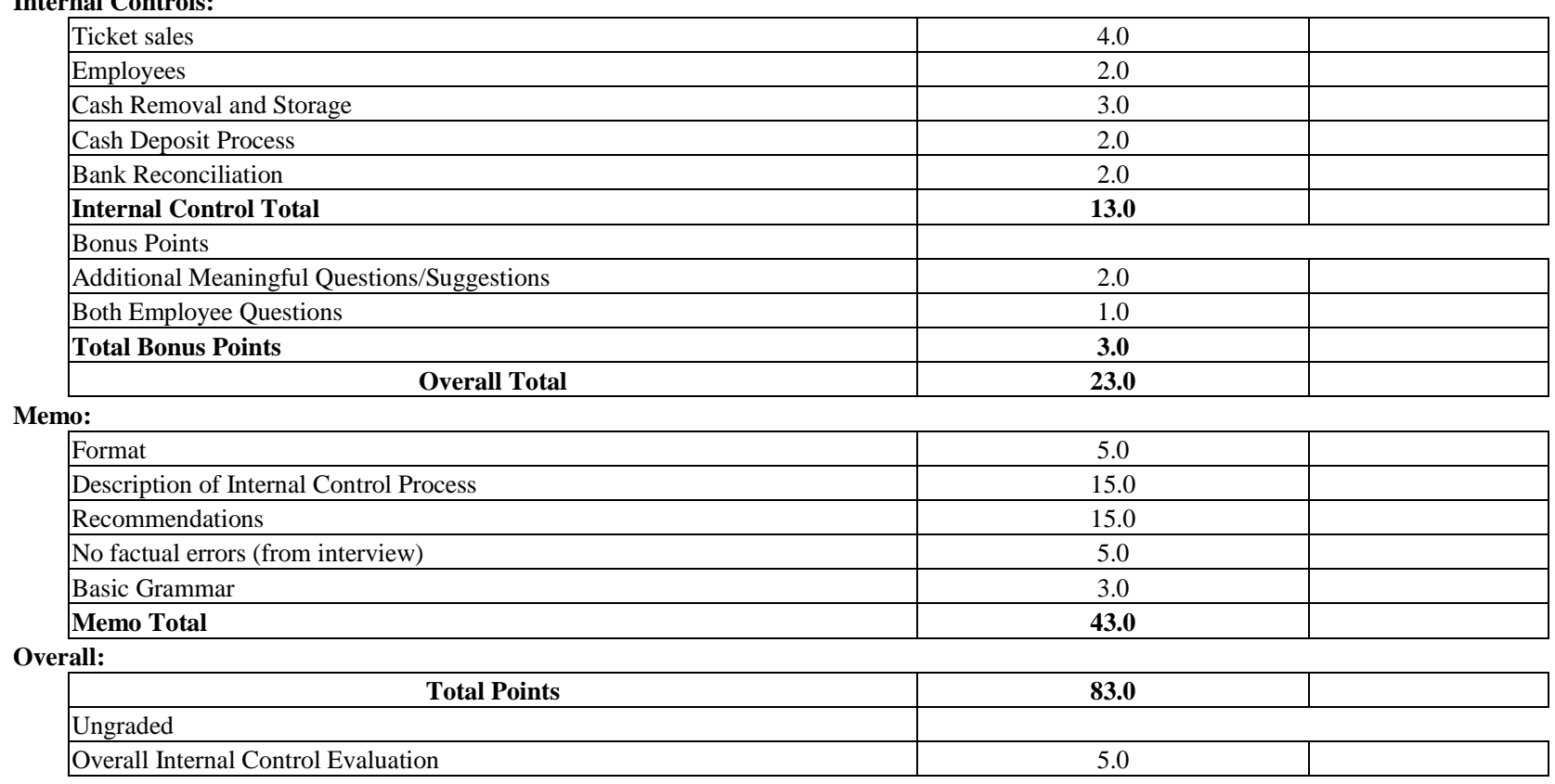




\title{
Exhibit 5
}

Practice Interview Questions

\begin{tabular}{|ll|}
\hline- & $\begin{array}{l}\text { Could you please walk me through your cash collection process, starting with the sale of tickets to when the } \\
\text { cash is deposited in the bank? }\end{array}$ \\
\hline - & Which individuals are responsible for each task? \\
\hline - & $\begin{array}{l}\text { Do employees ever rotate responsibilities or do they stay with the same job? What happens if a key individual } \\
\text { is not at work? }\end{array}$ \\
\hline - & How is the work double-checked? What control procedures do you undergo to ensure accuracy? \\
\hline - & $\begin{array}{l}\text { What controls are in place regarding cash collections? Does the register at the point of sale keep track of the } \\
\text { number of tickets sold? Is this number than reconciled with the amount of cash collected? }\end{array}$ \\
\hline - & How often is the cash deposited in the bank? \\
\hline - & Are bank statements reconciled with register totals? \\
\hline - & If discrepancies are found, what occurs next? \\
\hline & $\begin{array}{l}\text { Do you check the background of employees before hire? Are employees that handle cash bonded? Have there } \\
\text { been any problems with employee theft in the past? }\end{array}$ \\
\hline
\end{tabular}

\section{Exhibit 6 \\ SAMPLE STUDENT MEMO \\ Poor Control Scenario}

\author{
TO: $\quad 2004$ Audit Workpapers - Tecumseh Movie Theatre \\ FROM: $\quad$ Accounting Student, Staff Auditor \\ DATE: $\quad$ March 29, 2004 \\ SUBJECT: Cash Collection Internal Controls
}

On Saturday, March 27 I met with Mrs. Graduate Student, owner and manager of the Tecumseh Movie Theatre, to discuss internal controls for the cash collection process. As a family-owned business, this is the first time the adequacy of these controls has been examined.

According to the description given by Mrs. Graduate Student, the cash collection process used at Tecumseh is fairly simple and involves little use of internal controls. As customers buy tickets, employee Thelma Lou Smith takes the money, gives the appropriate change, and issues a movie ticket. Instead of a cash register, the money is placed in a cigar box under the counter. Approximately two times each night, Mrs. Graduate Student empties the money out of the cigar box. Each Saturday morning, Thelma Lou takes all cash received during the week, fills out a deposit slip, and takes the money to the bank to make the deposit.

Although this system hasn't produced any problems according to Mrs. Graduate Student, the use of internal controls is almost non-existent. Several faults exist within this structure:

- No cash register is used at the point-of-sale. For one, using a cash register provides much more security for keeping cash. Registers can also keep track of the number of tickets sold and the amount of money collected. These totals can be used later to reconcile the amount of cash collected and deposited. Finally, using a cash register ensures that no tickets can be issued without collecting the cash.

- There is no separation of duties. Employee Thelma Lou Smith not only collects the cash, but she totals the amount at the end of the week and prepares the bank deposit slip. With no register, these totals cannot be checked against any number. Thelma Lou has the opportunity to steal some of this cash with no way for Mrs. Graduate Student to know.

- $\quad$ Employees experience no rotation of responsibilities. Thelma Lou and Mrs. Graduate Student perform the same tasks each week with no rotation. If fraud were taking place, it would be much easier to detect if cash responsibilities changed. In addition, Thelma Lou Smith never misses work or takes vacation, making fraud detection difficult. 
- $\quad$ There is no way to check the accuracy of cash collections and cash deposits. Because of the procedure currently used, there is no way to reconcile cash deposits with the amount of cash collected each week. No discrepancies can be detected or corrected under the current system.

- $\quad$ Cash is only deposited in the bank one time each week. With the theatre open six days a week, this means a significant amount of cash is on hand at the theatre. More frequent deposits would increase the overall security of this money.

- $\quad$ Few controls exist to ensure the honesty of employees. Upon hire, no background checks are performed to review employment history. In addition, none of the employees with cash handling duties are bonded to insure against theft. The only deterrent for employee theft is the owner's shotgun.

Before our firm can write a clean opinion on this firm, the internal controls regarding cash collection need to undergo significant changes. Not only will this help with the audit, but these changes will undoubtedly improve the overall performance of this business.

\section{CONCLUSION}

The importance of good communication skills and the need for accounting education to address these skills is well documented in the literature. The purpose of this paper was to describe an assignment, interviewing a client, which can be used in either an introductory auditing course or accounting communications course. The assignment represents a typical responsibility of an entry-level accountant, and it allows students to develop and demonstrate their communication skills in a "real-world" setting. Any institution with graduate students or access to local practitioners can incorporate this assignment into the curriculum.

Acknowledgments: The authors would like to thank all of the graduate students and professionals that have played the role of the client.

\section{REFERENCES}

Harmeyer, W. James, et al. (May 1984) Conducting Internal Audit Interviews. Florida: IIA.

\section{APPENDIX A}

\section{INTERVIEW AND MEMO}

1. Information concerning an internal control situation will be distributed upon completion of Chapter 8 (Assessing Control Risk).

2. You are required to contact the graduate assistant (name omitted for paper), an employee of a fictitious client, to schedule an interview regarding the internal control situation. The purpose of your interview is to obtain an understanding of the internal control structure of the situation provided to you.

3. The graduate student's office is located in the basement of Straz Hall (business building). You must contact him personally - not by mail or phone. I recommend that you contact the graduate student as soon as possible to schedule your interview.

4. Interviews will be conducted from February 27 to March 27. The interview is not to exceed twenty minutes.

5. Upon completion of the interview, you are required to prepare a typed memo (not to exceed three pages). The memo should be given to me no later than March 30. You are also required to evaluate your performance in conducting the interview using the following scale:

Not Satisfactory

1
2
3
Very

Satisfactory

4 
The documentation of your score should be given to me, in a sealed envelope with your name on the outside, by March 30. Failure to complete your self-evaluation will result in a five-point deduction.

6. Basis for Grading:

a. Content and writing ability

b. Graduate student's evaluation Total

7. No late memos will be accepted.

$$
\begin{array}{r}
30 \text { points } \\
5 \text { points } \\
35 \text { points }
\end{array}
$$

\section{APPENDIX B}

\section{INTERNAL CONTROL - MOOVY THEATER}

\section{Introduction}

Taylor, Fife \& Campbell, a public accounting firm located in Raleigh, North Carolina, just obtained a new client. You joined the firm about a month ago and have just completed your initial training. You have been assigned to the Moovy Theater audit.

\section{Background Information}

Moovy Theater, which is located in Mayberry, North Carolina, is owned and managed by Mr. Tom Bode. The theater is a family business and was started by Mr. Bode's father-in-law, Gomer Pyle. The Moovy Theater shows the same movie twice each night (7:00 and 9:00 p.m.), Monday through Friday. On Saturdays, there is an afternoon matinee for the children along with the nightly showings. The theater is closed on Sunday.

Mr. Bode has noticed that attendance has increased significantly since the Highflyer Theater in Mount Pilot (approximately ten miles from Mayberry) closed last month. In fact, Mr. Bode has had to turn people away several nights.

Mr. Bode has decided to increase seating capacity. To obtain funding for this project, he applied for a loan from the Bank of Mayberry. Before the bank will grant a loan, the financial statements of the theater must be audited. The Moovy Theater has never been audited. Consequently, Mr. Bode is unfamiliar with the audit process.

\section{Audit Issues and Assignment}

The second standard of fieldwork states that an auditor must obtain a sufficient understanding of the internal control structure in order to plan the audit. Since movie theaters generate revenues primarily from ticket sales, controls for the sale of tickets and the collection and deposit of cash are important. In order to comply with the second standard of fieldwork, the senior on the engagement, Helen Crump, has asked you to interview Mr. Bode regarding the control procedures for the sale of tickets and the collection and deposit of cash. The results of your interview are to be documented in a memorandum.

Are we going to use Moovy Theater or Tecumseh Movie Theatre? 


\section{APPENDIX C \\ Poor Internal Control}

\begin{tabular}{|l|l|}
\hline Ticket Sales 1,2,3* & $\begin{array}{l}\text { Thelma Lou, a CPA who is no longer practicing, takes cash. Customers are provided an } \\
\text { unnumbered colored ticket. A different colored ticket is used for each day of the week. } \\
\text { Tickets are collected by part-time people. }\end{array}$ \\
\hline Employees 1, 3, 4* & $\begin{array}{l}\text { No employment history check is performed. Note: Thelma Lou is now married with a } \\
\text { family. That is the reason she is not practicing. }\end{array}$ \\
\hline $\begin{array}{l}\text { Physical Safeguards } \\
\text { (Upon Sale) 4* }\end{array}$ & Cash is stored in a drawer behind the counter. \\
\hline $\begin{array}{l}\text { Physical Safeguards } \\
\text { (Transfers To Safe) 2, 4* }\end{array}$ & $\begin{array}{l}\text { No safe exists. } \\
\text { Cash is kept in an unlocked file cabinet in Mr. Bode's office until the deposit is made } \\
\text { on Saturday morning. }\end{array}$ \\
\hline $\begin{array}{l}\text { Physical Safeguards } \\
\text { (Deposits) 4* }\end{array}$ & $\begin{array}{l}\text { Cash is counted and deposited each Saturday by Thelma Lou. Owner requires that the } \\
\text { deposit slip be returned to him on the day of the deposit. Deposit slips are kept in } \\
\text { owner's desk drawer. No cash receipts journal is maintained. }\end{array}$ \\
\hline Bank Reconciliation 5* & $\begin{array}{l}\text { Checkbook is kept. Bank reconciliations are performed by Thelma Lou but not } \\
\text { reviewed by Mr. Bode. }\end{array}$ \\
\hline
\end{tabular}

* Categories of control procedures:

1. Proper authorization of transactions and activities;

2. Segregation of duties;

3. Design and use of adequate documents and records;

4. Adequate safeguards over access to and use of assets and records;

5. Independent checks on performance and proper valuation of recorded amounts.

\section{APPENDIX D Moderate Internal Control}

\begin{tabular}{|c|c|}
\hline Ticket Sales 1, 2, 3* & $\begin{array}{l}\text { Thelma Lou, a full-time employee, takes cash and manually issues tickets that are pre- } \\
\text { numbered. Tickets are then collected by part-time ushers. Ticket numbers are } \\
\text { reconciled by Thelma Lou on a daily basis. }\end{array}$ \\
\hline Employees $1,3,4^{*}$ & $\begin{array}{l}\text { Employment application is completed; no check is performed on accuracy. No } \\
\text { references are contacted. Not bonded. }\end{array}$ \\
\hline $\begin{array}{l}\text { Physical Safeguards } \\
\text { (Upon Sale) } 4 *\end{array}$ & $\begin{array}{l}\text { Cash maintained in a modernized cash register that has a tape. Tapes are never used for } \\
\text { any purpose. }\end{array}$ \\
\hline $\begin{array}{l}\text { Physical Safeguards } \\
\text { (Transfers To Safe) } 2,4^{*}\end{array}$ & $\begin{array}{l}\text { The owner removes excess from the register on a regular basis ( } 2-3 \text { times per day), } \\
\text { counts it and stores it in a file cabinet in his office. (File cabinet and office are not } \\
\text { locked, but employees are not allowed in office.) }\end{array}$ \\
\hline $\begin{array}{l}\text { Physical Safeguards } \\
\text { (Deposits) } 4 *\end{array}$ & $\begin{array}{l}\text { Owner counts cash daily and records amounts in cash receipts journal. Thelma Lou } \\
\text { makes the daily deposit and the owner checks the deposit slip against the cash receipts } \\
\text { journal. }\end{array}$ \\
\hline Bank Reconciliation 5* & $\begin{array}{l}\text { Thelma Lou, the full-time employee, performs the reconciliation immediately upon } \\
\text { receipt of the bank statement. Reconciliation is reviewed by owner, only for accuracy. }\end{array}$ \\
\hline \multicolumn{2}{|c|}{ * Categories of control procedures: } \\
\hline $\begin{array}{l}\text { Proper authorizat } \\
\text { Segregation of du } \\
\text { Design and use of } \\
\text { Adequate safegua } \\
\text { Independent chec }\end{array}$ & $\begin{array}{l}\text { n of transactions and activities; } \\
\text { s; } \\
\text { dequate documents and records; } \\
\text { ls over access to and use of assets and records; } \\
\text { on performance and proper valuation of recorded amounts. }\end{array}$ \\
\hline
\end{tabular}




\section{APPENDIX E Good Internal Control}

\begin{tabular}{|l|l|}
\hline Ticket Sales 1,2,3* & $\begin{array}{l}\text { Thelma Lou takes cash and electronically issues ticket that is pre-numbered. Tickets } \\
\text { are then collected by part-time ushers. Ticket numbers are reconciled by owner on a } \\
\text { daily basis. }\end{array}$ \\
\hline Employees 1,3,4* & $\begin{array}{l}\text { Employment application is completed, accuracy is verified, and references are } \\
\text { contacted. Bonded. }\end{array}$ \\
\hline $\begin{array}{l}\text { Physical Safeguards } \\
\text { (Upon Sale) 4* }\end{array}$ & Cash maintained in a modern, computerized cash register that has a tape. \\
\hline $\begin{array}{l}\text { Physical Safeguards } \\
\text { (Transfers To Safe) } 2,4^{*}\end{array}$ & $\begin{array}{l}\text { The owner removes excess from the register on a regular basis (2-3 times per day) and } \\
\text { fills out a two-part "Cash Removed Ticket" by listing the cash and signing off. } \\
\text { Thelma Lou signs and counts also. Cash is then transferred to safe in owner's office. } \\
\text { Only owner and Thelma Lou know the combination to safe and office is locked. } \\
\text { Thelma Lou does not have a key to the office. }\end{array}$ \\
\hline $\begin{array}{l}\text { Physical Safeguards } \\
\text { (Deposits) 4* }\end{array}$ & $\begin{array}{l}\text { Cash register summary is printed out daily. Thelma Lou counts her own drawer and } \\
\text { reconciles to the tape. Owner reviews the reconciliation, makes out an overnight } \\
\text { deposit slip, updates the cash receipts journal, and deposits the cash in the overnight } \\
\text { drop at the bank on his way home each night. }\end{array}$ \\
\hline Bank Reconciliation 5* & $\begin{array}{l}\text { The owner performs monthly bank reconciliations and reconciles to the cash receipts } \\
\text { journal. }\end{array}$ \\
\hline
\end{tabular}

* Categories of control procedures:

1. Proper authorization of transactions and activities;

2. Segregation of duties;

3. Design and use of adequate documents and records;

4. Adequate safeguards over access to and use of assets and records;

5. Independent checks on performance and proper valuation of recorded amounts. 
NOTES 